\title{
Defisiensi ZincSebagai Salah Satu Faktor Risiko Diare Akut Menjadi Diare Melanjut
}

\author{
Dede Lia Marlia, Pramita G. Dwipoerwantoro, Najib Advani \\ Departemen Ilmu Kesehatan Anak Fakultas Kedokteran Universitas Indonesia/RS Dr. Cipto \\ Mangunkusumo, Jakarta
}

\begin{abstract}
Latar belakang. Diare masih merupakan penyebab morbiditas dan mortalitas yang cukup tinggi pada anak, dan efeknya akan meningkat pada diare melanjut. Ekskresi yang meningkat dan malnutrisi menimbulkan defisiensi makro dan mikronutrien, defisiensi zinc merupakan salah satu penyebabnya.

Tujuan. Mengetahui apakah defisiensi zinc merupakan faktor risiko diare akut menjadi diare melanjut. Metode. Penelitian uji potong lintang dilakukan di RSCM dan tiga rumah sakit umum daerah pada anak usia >1-60 bulan yang mengalami diare akut kurang dari 7 hari. Dilakukan anamnesis, pemeriksaan fisik, dan pemeriksaan kadar zinc serum.

Hasil. Analisis dilakukan pada 99 subjek. Usia terbanyak 12-36 bulan, perbandingan laki-laki perempuan 1,3:1. Prevalensi defisiensi zinc adalah 20,2\%. Insiden diare melanjut 25,3\%. Tidak terdapat hubungan antara defisiensi zinc dengan usia, status nutrisi, riwayat diare berulang, pendidikan ibu, dan pendapatan orangtua. Defisiensi zinc bukan merupakan faktor risiko diare akut menjadi diare melanjut RR 1,82 (IK95\% 0,633-5,260; $\mathrm{p}=0,261)$. Riwayat diare berulang merupakan faktor risiko diare akut menjadi diare melanjut RR 3,4 kali (IK95\% 1,3-9,5; p=0,013).

Kesimpulan. Defisiensi zinc bukan merupakan faktor risiko diare akut menjadi diare melanjut. Riwayat diare berulang berisiko untuk terjadinya diare akut menjadi diare melanjut. Sari Pediatri 2015;16(5):299-306.
\end{abstract}

Kata kunci: defisiensi zinc, diare akut, diare melanjut, diare berulang, anak

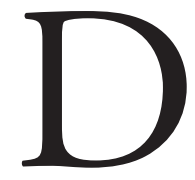
iare merupakan salah satu masalah kesehatan yang penting, terutama di negara berkembang. World Health Organization (WHO), pada tahun 2009, melaporkan setiap tahun terdapat 2,5 milyar anak di bawah usia 5

\footnotetext{
Alamat korespondensi:

Dr. Dede Lia Marlia. Departemen Ilmu Kesehatan Anak FKUI, Jakarta, Indonesia. Jalan Diponegoro no.71, Jakarta, 10430, Indonesia. Telp. (021) 3907742, Fax. (021) 3907743. E-mail:delima.dr@gmail.com.
}

tahun yang mengalami diare. ${ }^{1}$ Riset Kesehatan Dasar (Riskesdas 2007) menunjukkan insidens diare pada anak usia di bawah 5 tahun adalah $16,7 \%$, dan merupakan penyebab utama kematian pada bayi $(31,4 \%)$ dan usia di bawah 5 tahun $(25,2 \%) .^{2}$ Diare melanjut dapat menyebabkan malnutrisi, defisiensi mikronutrien, meningkatkan risiko morbiditas, dan mortalitas penyakit lain terkait diare serta berpengaruh terhadap pertumbuhan dan perkembangan. . $^{1,3,4}$

Sebagian besar diare akan sembuh dalam satu minggu, tetapi pada sejumlah kasus dapat berlanjut 
sampai lebih dari 14 hari. Saat ini, pembagian klinis diare meliputi diare akut, disentri, dan diare persisten. ${ }^{5,6}$ International persistent diarrhea working group menekankan perlunya menilai kondisi diare melanjut yakni diare yang berlangsung antara 7 hingga 13 hari karena berisiko menjadi diare persisten. ${ }^{78}$ Sebuah penelitian kohort, pada subjek usia satu tahun, menyimpulkan bahwa diare melanjut merupakan faktor risiko untuk terjadinya diare persisten dengan relative risk (RR) 6,09.7 Di negara berkembang, diare persisten menyumbang angka kematian yang tinggi, berkisar antara $23 \%$ sampai dengan 70\%. ${ }^{9}$ Pencegahan diare akut melanjut harus dilakukan karena merupakan faktor risiko untuk terjadinya diare persisten. Pada anak di negara berkembang, salah satu pilar tata laksana diare akut adalah suplementasi zinc yang bertujuan untuk mencegah diare berulang, melanjut atau persisten. ${ }^{10}$

Defisiensi zinc merupakan kondisi yang sering terjadi di negara berkembang. Secara global, prevalensi defisiensi zinc 31\% dengan kisaran $4 \%$ hingga $73 \%$. Prevalensi tertinggi didapatkan di Asia Tenggara dan Selatan (34\%-73\%). ${ }^{11}$ Berbagai masalah dapat timbul akibat defisiensi zinc. Sebuah telaah menunjukkan defisiensi zinc meningkatkan kejadian diare dan pneumonia. ${ }^{12}$ Penelitian Walker ${ }^{13}$ menunjukkan defisiensi zinc menyebabkan 4,4\% kematian pada anak di bawah 5 tahun dengan $14,4 \%$ di antaranya diakibatkan oleh diare.

Berbagai faktor risiko ditengarai berkonstribusi pada keadaan defisiensi zinc, di antaranya adalah asupan kandungan zinc yang rendah, kebutuhan meningkat, maupun ekskresi berlebihan, misalnya pada diare. ${ }^{11,14}$ Diare akan menyebabkan peningkatan ekskresi zinc dalam tinja, balans zinc yang negative, dan menurunkan konsentrasi zinc dalam jaringan. ${ }^{15}$ Penelitian di Delhi, India, didapatkan prevalensi defisiensi zinc 73,3\% pada anak usia prasekolah dengan diare akut. ${ }^{16}$ Penelitian pada diare persisten di Afrika didapatkan prevalensi defisiensi zinc mencapai $47,9 \% .{ }^{17}$ Pada diare, zinc berperan dalam inhibisi second messenger induced $\mathrm{Cl}$ secretion (cAMP, cGMP, ion kalsium) meningkatkan absorpsi natrium, memperbaiki permeabilitas intestinal, dan fungsi enzim pada enterosit, meningkatkan regenerasi epitel usus dan respons imun lokal dengan membatasi bacterial overgrowth, dan meningkatkan klirens patogen. ${ }^{15-17,20-21}$

Peneliti ingin mengetahui kadar zinc pada anak dengan diare dan kaitannya faktor yang memengaruhinya serta faktor risiko diare akut menjadi diare melanjut.

\section{Metode}

Penelitian potong lintang untuk melihat prevalensi defisiensi zinc pada diare akut dan faktor yang memengaruhinya, dan melihat hubungan defisiensi zinc dengan kejadian diare melanjut. Lokasi penelitian di Departemen IKA FKUI RSCM Jakarta, RSUD Budhi Asih Jakarta (RSBA), RSUD Bayu Asih Purwakarta, dan RSUD Sekarwangi Kabupaten Sukabumi. Perekrutan subjek secara convenient di poliklinik, instalasi gawat darurat, dan ruang perawatan. Pemeriksaan kadar zinc serum dilakukan di laboratorium SEAMEO Tropmed Regional Centre For Community Nutrition, UI. Waktu penelitian berlangsung dari 1 Oktober 2013 sampai dengan 30 November 2013. Subjek adalah usia $>1$ bulan hingga 60 bulan yang mengalami diare akut kurang dari 7 hari, dan orangtua bersedia mengikuti penelitian dengan menandatangani informed consent. Kriteria eksklusi meliputi gizi buruk, diare berdarah, infeksi HIV, dan penyakit penyerta.

Berdasarkan rumus proporsi tunggal, minimal besar sampel adalah 88 untuk studi potong lintang dan 25 untuk studi kohort. Dilakukan pencatatan data dasar yang dilakukan oleh peneliti dan tiga dokter umum yang sudah dilatih. Apabila subjek mengalami dehidrasi pengambilan spesimen dilakukan setelah pasien terehidrasi. Pengambilan sampel darah $3 \mathrm{~mL}$ untuk mengukur kadar zinc. Dalam waktu 30 menit-2 jam, setelah darah diambil, dilakukan centrifuge di laboratorium Perinatalogi RSCM dan Sayang Bunda di Purwakarta, lalu darah disimpan dalam suhu $-70^{\circ} \mathrm{C}$. Pemeriksaan kadar zinc dilakukan di Laboratorium SEAMEOUI dengan menggunakan metode fotometrik (kimia), dengan reagen titrisol zinc standar $1000 \mathrm{mg}$ dan alat AAS (Atomic Absorben Spektrofotometer) GBC 933 AA. Dikatakan defisiensi apabila kadar serum zinc $<9,9 \mu \mathrm{mol} / \mathrm{L}^{14}$

Untuk subjek rawat inap, pemantauan terhadap lama diare dilakukan setiap hari hingga subjek sembuh, sedangkan subjek rawat jalan dilakukan pemantauan melalui telepon. Dikatakan diare melanjut apabila diare berlangsung lebih dari 7 hari. Monitoring frekuensi dan konsistensi buang air besar berdasarkan skala tinja 
116 Subjek memenuhi kriteria inklusi
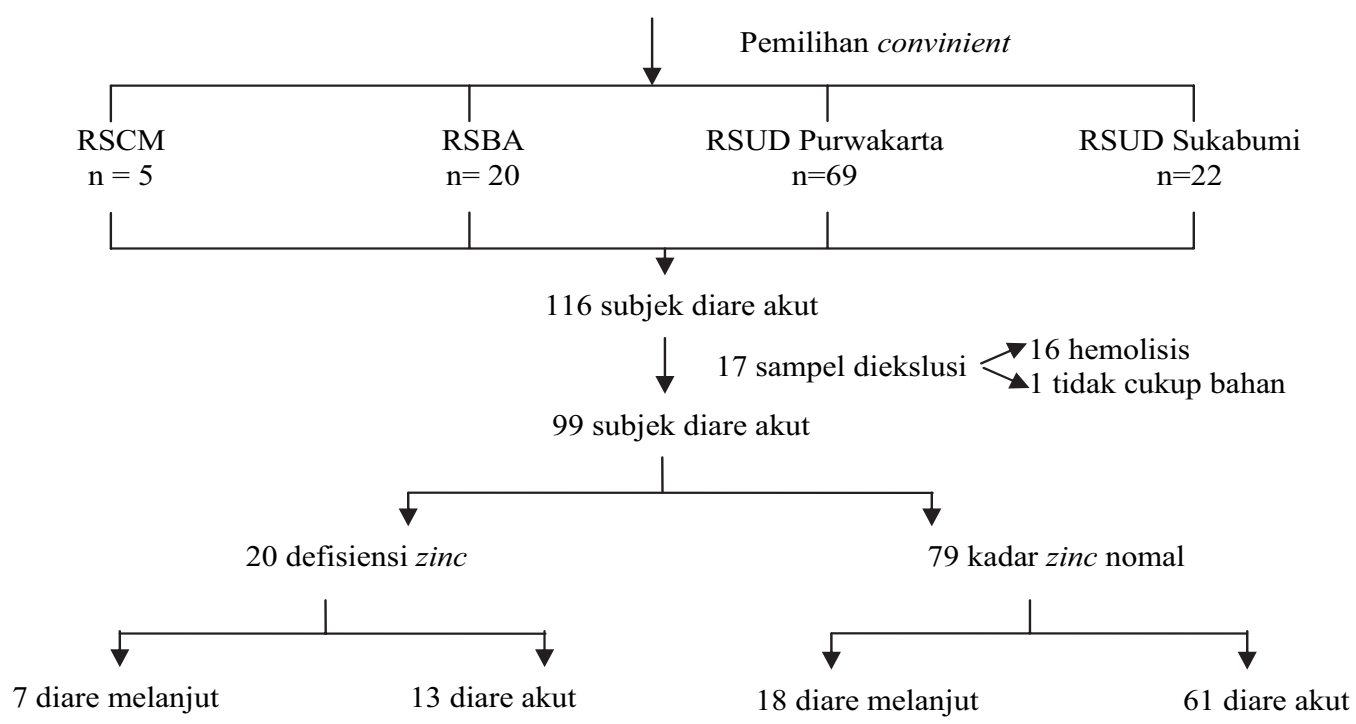

Gambar 1. Alur pengambilan subjek

Bristol. Dikatakan sembuh apabila memenuhi kriteria 5 berdasarkan skala tinja Bristol.

\section{Hasil}

Pada ke-4 lokasi perekrutan subjek. Didapatkan 116 subjek dari tetapi hanya 99 subjek yang dilakukan analisis, sisanya darah mengalami hemolisis (Gambar 1). Sebagian besar subjek penelitian berjenis kelamin laki-laki. Median usia subjek 14 bulan dengan rentang $2-52$ bulan dan sebagian besar (48\%) berada pada kelompok umur 12-36 bulan. Pendidikan ibu subjek sebagian besar adalah rendah dan menengah (95\%) dengan pendapatan orangtua yang rendah $(91 \%)$. Sebagian besar (64\%) subjek memiliki gizi cukup. Limapuluh dua persen subjek mempunyai riwayat pemberian antibiotik dan riwayat pemberian zinc (51\%) dengan rerata lama pemberian zinc 1,1 (SD 1,5) hari (Tabel 1).

Proporsi defisiensi zinc adalah 20/99 (20,2\%) dan distribusi subjek dengan defisiensi zinc dari keempat pengambilan sampel di RSCM, RSBA, RSUD Purwakarta, RSUD Sukabumi berturut-turut 20\% (1/5), 20\% (3/15), 21,7\% (13/60) dan 15,8\% (3/19). Pada Gambar 2 tampak sebaran kadar zinc kelompok normal dibandingkan kelompok defisiensi zinc. Setelah 2 outliers dikeluarkan dan dianalisis, didapatkan rerata kadar zinc kelompok defisiensi dibandingkan kelompok normal berbeda secara bermakna, yaitu $8,3(\mathrm{SD} 1,6) \mu \mathrm{mol} / \mathrm{L}$ vs. 13,2(SD 3,9) $\mu \mathrm{mol} / \mathrm{L}(\mathrm{p}=0,075)$.

Pada Gambar 3, tampak bahwa kadar zinc pada diare akut dibandingkan diare melanjut ternyata tidak berbeda bermakna $[12,9(\mathrm{SD} 3,6) \mu \mathrm{mol} / \mathrm{L} v$ s. 13,2(SD 3,9) $\mu \mathrm{mol} / \mathrm{L}(\mathrm{p}=0,075)]$.

Insiden diare melanjut 25/99 (25\%). Hasil analisis dengan chi square, defisiensi zinc bukan merupakan faktor risiko terjadinya diare melanjut pada penelitian ini, RR 1,82 (IK 95\% 0,633-5,260) dengan $\mathrm{p}=0,261$ (Tabel 2).

Pada subjek dengan defisiensi zinc dan diare melanjut, rerata kadar zinc 8,9 (SD 0,9) $\mu \mathrm{mol} / \mathrm{L}$. Selain faktor defisiensi zinc, dilakukan analisis untuk mengetahui faktor risiko diare melanjut dihubungkan dengan kondisi sosial ekonomi, usia, status nutrisi, dan riwayat diare berulang. Hasil analisis univariat, dari kelima variabel, hanya riwayat diare berulang yang menunjukkan hubungan bermakna. Dengan demikian, analisis multivariat (regresi logistik) tidak dapat dilakukan. Subjek dengan riwayat diare berulang memiliki risiko 3,4 kali (IK95\% $1,3-9,5)$ dengan $\mathrm{p}=0,013$ untuk terjadinya diare melanjut (Tabel 3). 
Tabel 1. Karakteristik subjek

\begin{tabular}{|c|c|c|}
\hline Karakteristik & Jumlah $(n=99)$ & $\%$ \\
\hline \multicolumn{3}{|l|}{ Jenis kelamin } \\
\hline Laki-laki & 56 & 57 \\
\hline Perempuan & 43 & 43 \\
\hline \multicolumn{3}{|l|}{ Kategori usia (bulan) } \\
\hline $1-6$ & 9 & 9 \\
\hline$>6-12$ & 39 & 39 \\
\hline$>12-36$ & 47 & 48 \\
\hline$>36-60$ & 4 & 4 \\
\hline \multicolumn{3}{|l|}{ Pendidikan ibu } \\
\hline Rendah & 60 & 61 \\
\hline Menengah & 34 & 34 \\
\hline Tinggi & 5 & 5 \\
\hline \multicolumn{3}{|l|}{ Pendapatan orangtua } \\
\hline Rendah & 90 & 91 \\
\hline Menengah ke bawah & 9 & 9 \\
\hline \multicolumn{3}{|l|}{ Status gizi } \\
\hline Obesitas & 4 & 4 \\
\hline Gizi lebih & 2 & 2 \\
\hline Baik & 63 & 64 \\
\hline Kurang & 30 & 30 \\
\hline \multicolumn{3}{|l|}{ Riwayat diare berulang } \\
\hline $\mathrm{Ya}$ & 22 & 22 \\
\hline Tidak & 77 & 78 \\
\hline \multicolumn{3}{|l|}{ Riwayat terapi zinc } \\
\hline $\mathrm{Ya}$ & 50 & 51 \\
\hline Tidak & 49 & 49 \\
\hline \multicolumn{3}{|l|}{ Riwayat antibiotik } \\
\hline $\mathrm{Ya}$ & 51 & 52 \\
\hline Tidak & 48 & 48 \\
\hline
\end{tabular}

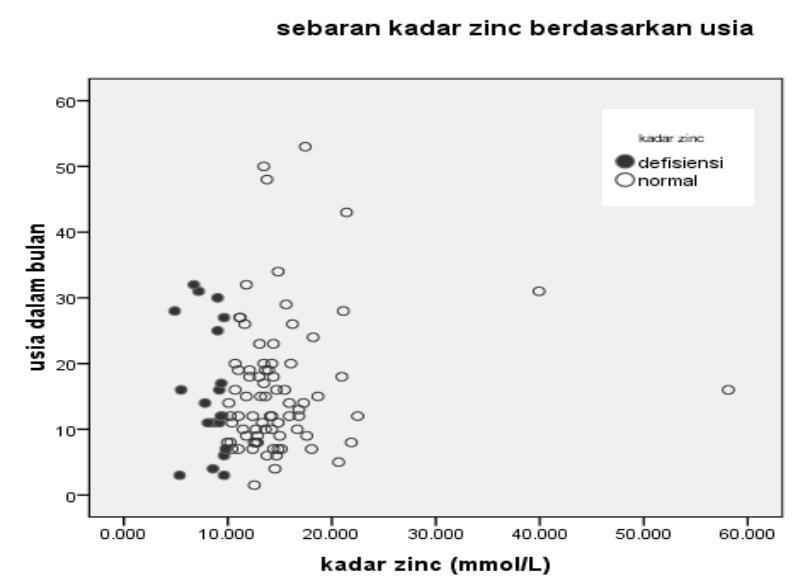

Gambar 2. Sebaran kadar zinc ( $\mu \mathrm{mol} / \mathrm{L})$

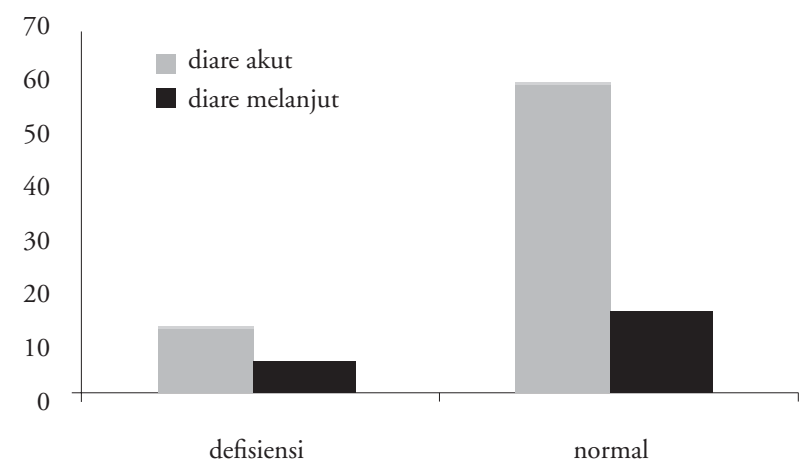

Gambar 3. Distribusi kadar zinc pada diare akut dan diare melanjut

\section{Pembahasan}

Pada penelitian ini proporsi defisiensi zinc 20,2\%. Defisiensi zinc secara global memiliki prevalensi 4\%-73\%. ${ }^{11}$ Hasil tersebut lebih rendah dibandingkan prevalensi di India, yakni 73,3\% pada diare akut. ${ }^{18}$ Perbedaan ini disebabkan karena jumlah subjek rendah (99 subjek), sedangkan di India melibatkan 940 subjek. Penggunaan cutt-offdefisiensi zinc yang berbeda, di India lebih tinggi 10,7 $\mu \mathrm{mol} / \mathrm{L}$ (berdasarkan WHO), sedangkan penelitian ini 9,9 $\mu \mathrm{mol} / \mathrm{L}$ yang menyebabkan defisiensi zinc di India terjaring lebih banyak. Pada studi ini, malnutrisi berat dieksklusi sehingga memengaruhi prevalensi defisiensi zinc yang lebih rendah dibandingkan studi di India yang mengikutsertakan malnutrisi berat. Penelitian ini lebih banyak dengan gizi cukup (64\%), sedangkan di India gizi baik hanya sekitar 35\%.

Faktor sosial ekonomi, tingkat pendidikan ibu dan pendapatan orangtua, tidak memiliki hubungan dengan timbulnya defisiensi zinc. Hasil tersebut seiring dengan penelitian di Thailand yang tidak mendapatkan hubungan antara kadar zinc dengan status sosial ekonomi. ${ }^{22}$ Berbeda halnya dengan $\mathrm{IZ}_{\text {inc }} \mathrm{G}^{14}$ yang menyebutkan bahwa kondisi sosial ekonomi rendah merupakan kelompok berisiko untuk terjadinya defisiensi zinc. Pemikiran tanah di tempat subjek tinggal mengandung kadar zinc cukup menjadi salah satu alasan kadar zinc tidak berkorelasi dengan sosial ekonomi yang rendah karena hanya seperempat tanah di dunia yang mengandung kadar zinc yang rendah. Selain itu, subjek juga menggunakan sumber air negara dan tidak semata mengandalkan sumber air tanah. ${ }^{23}$ Tanah mengandung sekitar $55 \mathrm{mg}$ zinc/kg tanah dengan rentang 10-300 mg. Di Indonesia (Sumatera 
Tabel 2. Hubungan defisiensi zinc dengan usia, status gizi, riwayat diare berulang, pendidikan ibu, dan pendapatan orangtua

\begin{tabular}{|c|c|c|c|c|c|c|c|c|}
\hline \multirow[b]{2}{*}{ Karakteristik } & \multicolumn{4}{|c|}{ Status zinc } & \multirow{2}{*}{$\mathrm{p}$} & \multirow{2}{*}{ OR } & \multicolumn{2}{|c|}{ IK $95 \%$} \\
\hline & Defisiensi & $\%$ & Normal & $\%$ & & & Bawah & Atas \\
\hline \multicolumn{9}{|l|}{ Kategori usia (bulan) } \\
\hline $1-12$ & 10 & 20,8 & 38 & 79,2 & 0,879 & 1,08 & 0,404 & 2,879 \\
\hline $12-60$ & 10 & 19,6 & 41 & 80,4 & & & & \\
\hline \multicolumn{9}{|l|}{ Pendapatan orangtua } \\
\hline Rendah & 18 & 20,0 & 72 & 80,0 & $1,000^{\mathrm{b}}$ & 0,88 & 0,167 & 4,575 \\
\hline Menengah ke bawah & 2 & 22,2 & 7 & 77,8 & & & & \\
\hline \multicolumn{9}{|l|}{ Pendidikan ibu } \\
\hline Rendah & 11 & 18,3 & 49 & 81,7 & $0,566^{\mathrm{a}}$ & 0,75 & 0,278 & 2,016 \\
\hline Menengah & 8 & 23,5 & 26 & 76,5 & & & & \\
\hline Tinggi & 1 & 20,0 & 4 & 80,0 & & & & \\
\hline \multicolumn{9}{|l|}{ Status gizi } \\
\hline Gizi kurang & 8 & 26,7 & 22 & 73,3 & $0,291^{\text {a }}$ & 1,73 & 0,622 & 4,795 \\
\hline Gizi baik & 10 & 15,9 & 53 & 84,1 & & & & \\
\hline Gizi lebih & 0 & 0,0 & 2 & 100,0 & & & & \\
\hline Obesitas & 2 & 50,0 & 2 & 50,0 & & & & \\
\hline \multicolumn{9}{|l|}{ Riwayat diare berulang } \\
\hline $\mathrm{Ya}$ & 4 & 18,2 & 18 & 81,8 & $1,000^{\mathrm{b}}$ & 0,85 & 0,251 & 2,856 \\
\hline Tidak & 16 & 20,8 & 61 & 79,2 & & & & \\
\hline
\end{tabular}

${ }^{\mathrm{a}} \mathrm{Uji}$ kemaknaan dengan chi-square.dengan terlebih dahulu menggabungkan sel variabel independen (rendah, menengah tinggi; gizi kurang, gizi baik-obesitas), ${ }^{b} U j i$ signifikansi dengan Fisher; cOR, crude Odds ratio, nilai p bermakna bila $\mathrm{p}<0,05$.

Tabel 3. Hubungan kadar zinc dengan diare melanjut

\begin{tabular}{|c|c|c|c|c|c|c|c|c|}
\hline \multirow[b]{2}{*}{ Karakteristik } & \multicolumn{4}{|c|}{ Diare melanjut } & \multirow{2}{*}{$\mathrm{p}$} & \multirow{2}{*}{$\mathrm{RR}$} & \multicolumn{2}{|c|}{ IK95\% } \\
\hline & $\mathrm{Ya}$ & $\%$ & Tidak & $\%$ & & & Bawah & Atas \\
\hline \multicolumn{9}{|l|}{ Kadar zinc } \\
\hline Defisiensi & 7 & 35,0 & 13 & 65,0 & 0,261 & 1,82 & 0,633 & 5,260 \\
\hline Normal & 18 & 22,8 & 61 & 77,2 & & & & \\
\hline
\end{tabular}

Uji kemaknaan dengan Chi-square; cRR, crude risk ratio, nilai p bermakna bila $p<0,05$

dan Sulawesi), kondisi tanah mengandung 33-174 mg zinc/kg tanah. ${ }^{24}$ Namun demikian, hal tersebut tidak dapat disimpulkan dari penelitian ini.

Pada analisis, kelompok usia dibagi menjadi dua, kurang dari 1 tahun dan $>1-5$ tahun. Defisiensi zinc kedua kelompok usia tersebut tidak berbeda sehingga tidak ada hubungan antara kelompok usia dengan defisiensi zinc. Usia di atas 1 tahun dikatakan lebih rentan untuk terjadinya defisiensi. Saat usia tersebut sebagian besar anak sudah tidak mendapat air susu ibu (ASI), kandungan zinc dalam ASI dinilai cukup dalam memenuhi kebutuhan zinc tubuh terutama pada bayi kurang dari 6 bulan. Pada awal menyusui, kadar zinc ASI lebih tinggi, lalu menurun. Konsentrasinya sekitar 2,5 mg/hari lalu menurun hingga $0,8 \mathrm{mg} / \mathrm{hari}$ saat bulan ke-6 pasca melahirkan. Food and Nutrition Board Amerika Serikat merekomendasikan asupan zinc $2 \mathrm{mg} /$ hari untuk bayi di bawah 6 bulan, sedangkan rekomendasi WHO 0,7-1,3 mg/hari dan itu sudah mencukupi dari ASI. Pemberian makanan tambahan, seperti sereal, buah-buahan, dan sayuran sebenarnya dapat memenuhi kebutuhan zinc pada bayi usia lebih 6 bulan, tetapi zat inhibitor $z i n c$ pada sumber makanan tersebut juga tinggi. ${ }^{14,25}$ Selain itu, prevalensi masalah makan usia di atas 1 tahun lebih tinggi dibandingkan usia sebelumnya. ${ }^{14}$ Sayangnya, data asupan tidak diambil dan data pemberian ASI tidak lengkap pada penelitian ini sehingga tidak dapat dievaluasi. 
Tabel 4. Hubungan diare melanjut dengan usia, status gizi, riwayat diare berulang, pendidikan ibu, dan pendapatan orangtua

\begin{tabular}{|c|c|c|c|c|c|c|c|c|c|}
\hline \multirow{2}{*}{ Variabel } & \multirow{2}{*}{ Kategori } & \multicolumn{4}{|c|}{ Diare melanjut } & \multirow{2}{*}{$\mathrm{p}$} & \multirow{2}{*}{ OR } & \multicolumn{2}{|c|}{ IK 95\% } \\
\hline & & Ya & $(\%)$ & Tidak & $(\%)$ & & & Bawah & Atas \\
\hline \multicolumn{10}{|c|}{ Usia (bulan) } \\
\hline & $1-12$ & 14 & 29,17 & 34 & 70,83 & \multirow{2}{*}{0,384} & \multirow{2}{*}{1,50} & \multirow{2}{*}{0,601} & \multirow{2}{*}{3,729} \\
\hline & $13-60$ & 11 & 21,57 & 40 & 78,43 & & & & \\
\hline \multicolumn{10}{|c|}{ Pendapatan } \\
\hline & Rendah & 24 & 26,70 & 66 & 73,30 & \multirow{2}{*}{0,442} & \multirow{2}{*}{2,91} & \multirow{2}{*}{0,345} & \multirow{2}{*}{24,497} \\
\hline & Menengah rendah & 1 & 11,10 & 8 & 88,90 & & & & \\
\hline \multicolumn{10}{|c|}{ Pendidikan } \\
\hline & Rendah & 15 & 25,00 & 45 & 75,00 & \multirow{2}{*}{0,943} & \multirow{2}{*}{0,97} & \multirow{2}{*}{0,383} & \multirow{2}{*}{2,441} \\
\hline & Menengah-tinggi & 10 & 25,64 & 29 & 74,36 & & & & \\
\hline \multicolumn{10}{|l|}{ Gizi } \\
\hline & Kurang & 9 & 30,00 & 21 & 70,00 & \multirow{2}{*}{0,473} & \multirow{2}{*}{1,42} & \multirow{2}{*}{0,543} & \multirow{2}{*}{3,709} \\
\hline & Baik-obesitas & 16 & 23,19 & 53 & 76,81 & & & & \\
\hline \multicolumn{10}{|c|}{ Riwayat diare berulang } \\
\hline & $\mathrm{Ya}$ & 10 & 45,45 & 12 & 54,55 & \multirow{2}{*}{0,013} & \multirow{2}{*}{3,44} & \multirow{2}{*}{1,253} & \multirow{2}{*}{9,467} \\
\hline & Tidak & 15 & 19,48 & 62 & 80,52 & & & & \\
\hline
\end{tabular}

Malnutrisi memiliki hubungan yang erat dengan defisiensi zinc. Laporan data di Vietnam, kejadian defisiensi zinc hampir $50 \%$ anak dengan malnutrisi. ${ }^{16}$ Selain faktor asupan makronutrien dan mikronutrien yang kurang baik, kondisi hipoalbuminemia, anak dengan malnutrisi lebih rentan terhadap infeksi sehingga menambah kemungkinan kekurangan kadar zinc. ${ }^{14,16} \mathrm{Di}$ Nepal, suatu studi potong lintang melaporkan kondisi penurunan albumin plasma $1 \mathrm{~g} / \mathrm{L}$ akan terjadi penurunan kadar zinc plasma sebesar 0,25 $\mu \mathrm{mol} / \mathrm{L}$ (IK 95\% 0,21-0,29). ${ }^{26}$ Pada penelitian ini, status gizi tidak memengaruhi terjadinya defisiensi zinc. Hal tersebut dapat dipahami karena kebanyakan subjek memiliki gizi cukup yakni 64\%.

Secara umum, diare akan menyebabkan peningkatan ekskresi zinc feses, membuat balans negatif, dan mengurangi kadar zinc dalam jaringan. ${ }^{15,16}$ Jadi, semakin lama dan sering diare, tentunya akan meningkatkan kerentanan defisiensi zinc. Pada penelitian ini, riwayat diare berulang tidak berhubungan dengan defisiensi zinc. Hal tersebut dapat bermakna beberapa hal, pertama sejak awal subjek memang tidak defisiensi dan kedua kontrol hemostatic zinc yang efektif pada subjek. Sayangnya, untuk membuktikan tersebut salah satunya dengan pemeriksaan kadar zinc feses tidak dilakukan pada penelitian ini.

Insiden diare melanjut $5,3 \%$. Tidak ada data preva- lensi diare melanjut, tetapi menurut $\mathrm{WHO}$ anak usia di bawah 5 tahun dengan diare akut dapat menjadi diare persisten pada 3\% hingga 20\% kasus. ${ }^{27}$ Pada penelitian ini, setelah dilakukan analisis, defisiensi zinc tidak merupakan faktor risiko diare akut menjadi diare melanjut. Walaupun demikian, hasil penelitian ini mendapatkan kecenderungan insiden diare melanjut lebih banyak pada subjek defisiensi zinc daripada yang normal. Selain itu, terdapat satu subjek yang mengalami defisiensi zinc, datang dengan diare akut dehidrasi berat, dan dalam follow-up subjek tersebut mengalami diare melanjut. Suatu studi kohort yang membandingkan subjek defisiensi zinc dengan subjek normal menunjukkan bahwa kadar zinc yang rendah berhubungan dengan insiden dan tingkat keparahan diare yang lebih tinggi ${ }^{28}$ Studi oleh the zinc investigators collaborative group mendapatkan bahwa terapi zinc akan menurunkan diare akut melanjut dan menurunkan kegagalan terapi atau kematian pada diare persisten. ${ }^{29}$

Riwayat diare berulang berhubungan dengan diare melanjut. Subjek dengan riwayat diare berulang memiliki risiko 3,4 kali untuk terjadinya diare melanjut. Diare berulang dapat disebabkan kerusakan mukosa usus akibat infeksi yang belum sempurna penyembuhannya, alergi makanan atau defisiensi disakaridase. Namun, mekanisme penyembuhan mukosa usus yang belum sempurna pasca infeksi maupun infeksi baru dipercaya 
menjadi penyebab tersering sehingga berisiko untuk terjadinya diare melanjut. ${ }^{30}$ World Healtch Organizati meetings menyimpulkan bahwa diare persisten lebih sering terjadi pada usia 1 tahun, malnutrisi, gangguan imunologis, riwayat diare akut 2 bulan sebelumnya, episode diare persisten 1 tahun sebelumnya, dan kesulitan makan sebelumnya. ${ }^{27}$

Kadar zinc sebagai faktor yang diteliti tidak disertai data asupan makanan pada penelitian ini. Selain itu, riwayat mendapat terapi zinc sebelumnya tidak dieksklusi sehingga dapat memengaruhi kadar zinc yang diperiksa. Meskipun demikian, pengaruh ini dapat dihilangkan karena studi di Turki, pada subjek usia 6-60 bulan dengan diare akut, kadar zinc serum baru meningkat secara bermakna apabila pemberian zinc $15-30 \mathrm{mg}$ selama 14 hari. $^{31}$ Sebuah telaah sistemik pada subjek anak menemukan tidak diare, kadar zinc serum memiliki konsentrasi yang meningkat secara bermakna setelah pemberian lama (215 bulan). Pada subjek dewasa, peningkatan kadar terjadi setelah suplementasi minimal 6 hari. ${ }^{32}$ Pada penelitian ini, rerata lama pemberian zinc 1,1 hari sehingga mungkin kadar zinc serum tidak meningkat secara bermakna. Masalah teknis pengambilan sampel darah memengaruhi hasil kadar zinc (hemolisis) dan menyebabkan berkurangnya jumlah sampel penelitian cukup banyak.

Pemeriksaan kadar zinc serum dilakukan setelah semua sampel atau minimal lebih dari 50 sampel. Dengan demikian, pengamatan tidak berdasarkan kadar zinc serum, tetapi semua subjek diamati untuk terjadinya diare melanjut tanpa menunggu hasil kadar zinc serum terkait waktu yang terbatas. Kondisi ini tidak bisa dihindari karena pemeriksaan kadar zinc serum diperoleh setelah 10-14 hari. Keterbatasan lain dari penelitian ini adalah pengambilan subjek secara convinient sehingga mungkin memengaruhi keterwakilan populasi terjangkau.

Sebagai kesimpulan, defisiensi zinc bukan merupakan faktor risiko diare akut menjadi melanjut, tetapi dengan catatan bahwa diperlukan jumlah subjek lebih banyak yang mengalami defisiensi. Penelitian ini juga mendapatkan bahwa diare berulang merupakan salah satu faktor risiko diare akut menjadi diare melanjut.

\section{Daftar pustaka}

1. WHO. Diarrhea: Why children are still dying and what can be done. Diakses 8 Februari 2013. Diunduh dari:http:// whqlibdoc.who.int/publications/2009/9789241598415_eng. $p d f$.

2. Report on Result of National Basic Health Research (RISKESDAS 2007). Diakses 8 Februari 2013.Diunduh dari: http://203.90.70.117/searo/Indonesia/LinkFiles/Health_ Information_and_evidence_for_policy_Riskesdas_2007.pdf.

3. Ricci KA, Girosi F, Tarr PI, LimYW, Mason C, Miller M, dkk. Reducing stunting among children: the potential contribution of diagnostics. Nature 2006;444:29-38.

4. Moore SR. Update on prolonged and persistent diarrhea in children. Curr Opin Gastroenterol 2011:27;19-23.

5. Farthing M, Lindberg G, Dite P, Khalif I, Salazar-Lindo E, Ramakrishna BS, dkk. World gastroenterology organisation practice guideline: acute diarrhea. March 2008. Diakses 13 Maret 2013. Diunduh dari:http://www. worldgastroenterology.org/assets/downloads/en/pdflguidelines/01_ acute_diarrhea.pdf.

6. Guarino A, De Marco G. Persistent diarrhea. Dalam: Walker WA, Goulet O, Kleinman RE, Sherman PM, Shneider BL, Sanderson IR, penyunting. Pediatric gastrointestinal disease. Edisi ke-4. Hamilton, Ontario: BC Decker;2004.h.180-93.

7. Moore SR, Lima NL, Soares AM, Oria RB, Pinkerton RC, Barrett LJ, dkk. Prolonged episodes of acute diarrhea reduce growth and increase risk of persistent diarrhea in children. Gastroenterol 2010;139:1156-64.

8. Bhutta ZA, Nelson EA, Lee WS, Tarr PI, Zablah R, Phua KB, dkk. Recent advances and evidences gaps in persistent diarrhea. J Pediatr Gastroenterol Nutr 2008; 47:260-5.

9. Bern C. Diarrhoeal disease. Global epidemiology of infectious disease. Diakses 26 April 2012. Diunduh dari: http://whqlibdoc.who.int/publications/2004/9241592303. $p d f$.

10. World Health Organization. The treatment of diarrhoea. A manual for physicians and other senior health workers. Diakses tanggal 2 Juli 2013. Diunduh dari: http:// whqlibdoc.who.int/hq/2003/WHO_FCH_CAH_03.7.pdf.

11. Caulfield LE, Black RE. Zinc deficiency. Diakses tanggal 24 Juni 2013. Diunduh dari: www.who.int/publications/cral chapters/volume1/0257-0280pdf.

12. Walker CLF, Black RE. Functional indicators for assessing zinc deficiency. Food Nutr Bull 2007;3:S454-79.

13. Walker CLF, Ezzati M, Black RE. Global and regional child mortality and burden of disease attributable to zinc deficiency. Eur J Clin Nutr 2009:63;591-7.

14. International Zinc Nutrition Consultative Group (IZincG), Hotz C, Brown KH, penyunting. Assessment of the risk of zinc deficiency in population and options 
for itscontrol [Technical Document]. Food Nutr Bull 2004;25:94-204.

15. Scrimgeour AG, Lukaski HC. Zinc and diarrheal disease: current status and future perspectives. Curr Opin Clin Nutr Metab Care 2008;11:711-7.

16. Wapnir RA. Zinc deficiency, malnutrition and gastrointestinal tract. J Nutr 2000;130:1388S-92S.

17. Cuevas LE, Koyanagi A. Zinc and infection: a review. Ann Trop Paediatr 2005;25:149-60.

18. Dhingra U, Hiremath G, Menon VP, Dhingra P, Sarkar A, Sazawal S. Zinc deficiency: descriptive epidemiology and morbidity among preschool children in peri-urban population in Delhi, India. J Health Popul Nutr 2009;27:632-9.

19. Bitarakwate E, Mworozi E, Kekitiinwa A. Serum zinc status of children with persistent diarrhea admitted to diarrhea management unit of Mulago hospital, Uganda. Afr Health Sci 2003;3:54-60.

20. Hoque KM, Sarker R, Guggino SE, Tse CM. A new insight into pathophysiological mechanisms of zinc in diarrhea. Ann NY Acad Sci 2009;1165:279-84.

21. Lazzerini M, Ronfani L. Oral zinc for treating diarrhoea in children. Cochrane Database of Systematic Reviews 2013, Issue 1. Diakses tanggal 22 Juni 2013. Diunduh dari: http://www.bibliotecacochrane.com/pdf/CD005436.pdf.

22. Thurlow RA, Winichagoon P, Pongcharoen T, Gowachirapant S, Boonpraderm A, Manger MS dkk. Risk of zinc, iodine and other micronutrient defeiciencies among school children in North East Thailand. Eur J Clin Nutr 2006;60:623-32.

23. Nielsen FH. History of zinc in agriculture. Adv Nutr. 2012;3:783-9.

24. Alloway BJ. Zinc in soils and crop nutrition. Edisi ke-2. Brussels and Paris: IZA and IFA; 2008.h.1-139.

25. Krebs NF, Westcott J. Zinc and breastfed infants: if and when is there a risk of deficiency? Adv Exp Med Biol 2002;503:69-75.

26. Schneider JM, Fujii ML, Lamp CL, Lonnerdal B, Zidenberg-cherr $S$. The prevalence of low serum zinc and copper levels and dietary habits associated with serum zinc and copper in 12 to 36 month old children from low income families at risk for iron deficiency. J Am Diet Assoc 2007;107:1924-9.

27. World Health Organization. Diarrhoeal disease control programme. Persistent diarrhea in children in developing countries: memorandum from a WHO meeting. Bull World Health Org 1988:66;709-17.

28. Bahl R, Bhandari N, Hambidge M, Bhan MK. Plasma zinc as predictor of diarrheal and respiratory morbidity in children in an urban slum setting. Am J Clin Nutr 1998;68:414S-7S.

29. Bhutta ZA, Bird SM, Black RE, Brown KH, Gardner JM, Hidayat A, dkk. Zinc investigators collaborative group. Therapeutic effects of oral zinc in acute and persistent diarrhea in children in developing countries: pooled analysis of randomized controlled trials. Am J Clin Nutr 2000;72:1516-22.

30. Guarino A, De Marco G. Persistent diarrhea. Dalam: Walker WA, Goulet O, Kleinman RE, Sherman PM, Shneider BL, Sanderson IR, penyunting. Pediatric gastrointestinal disease. Edisi ke-4. Hamilton, Ontario: BC Decker;2004.h.180-93.

31. Brown KH, Peerson JM, Rivera J, Allen LH. Effect of supplemental zinc on the growth and serum zinc concentrations of prepubertal children: a meta-analysis of randomized controlled trials. Am J Clin Nutr 2002;75:1062-71.

32. Hess SY, Peerson JW, King JC, Brown KH. Use of serum zinc concentration as an indicator of population zinc status. Food Nutr Bull 2007;28:S403-29. 